\title{
The effects of milking frequency on insulin-like growth factor I signaling within the mammary gland of dairy cows
}

\author{
R. Murney, ${ }^{*} \dagger^{1}$ K. Stelwagen, $\ddagger$ T. T. Wheeler, ${ }^{*}$ J. K. Margerison, $\dagger$ and K. Singh ${ }^{*}$ \\ *AgResearch Ltd., Ruakura Research Centre, PB 3123, Hamilton 3240, New Zealand \\ †Institute of Agriculture and Environment, College of Sciences, Massey University, PB 11222, Palmerston North 4442, New Zealand \\ ¥SciLactis Ltd., Waikato Innovation Park, Hamilton 3240, New Zealand
}

\section{ABSTRACT}

In dairy cows, short-term changes in milking frequency (MF) in early lactation have been shown to produce both an immediate and a long-term effect on milk yield. The effect of MF on milk yield is controlled locally within mammary glands and could be a function of changes in either number or activity of secretory mammary epithelial cells (MEC). Insulin-like growth factor I (IGF-I) signaling is one candidate factor that could mediate these effects, as it can be controlled locally within mammary glands. Both MEC number and activity can be affected by IGF-I signaling by activating the phosphoinositide 3-kinase (PI3K)/Akt and extracellular-signal-regulated kinase (ERK) $1 / 2$ pathways. To investigate the relationship between MF and IGF-I signaling, udder halves of 17 dairy cows were milked either 4 times a day $(4 \times)$ or once a day $(1 \times)$ for $14 \mathrm{~d}$ in early lactation. On d 14, between 3 and 5 $\mathrm{h}$ following milking, mammary biopsies were obtained from 10 cows from both udder halves, and changes in the expression of genes associated with IGF-I signaling and the activation of the PI3K/Akt and ERK1/2 pathways were measured. The mRNA abundance of IGF type I receptor, IGF binding protein $(I G F B P)-3$, and $I G F B P-5$ were lower following $4 \times$ milking relative to $1 \times$ milking. However, the mRNA abundance of $I G F-I$ was not affected by MF. Both IGFBP3 and IGFBP5 are thought to inhibit IGF-I; therefore, decreases in their mRNA abundance may serve to stimulate the IGF-I signal in the $4 \times$-milked mammary gland. The activation of PI3K/Akt pathway was lower in response to $4 \times$ milking relative to $1 \times$, and the activation of the ERK1/2 was unaffected by MF, suggesting that they do not mediate the effects of MF.

Key words: milking frequency, mammary, milk synthesis, cell signaling

Received February 4, 2015.

Accepted April 22, 2015.

${ }^{1}$ Corresponding author: regan.murney@agresearch.co.nz

\section{INTRODUCTION}

In early lactation, short-term changes of milking frequency (MF) have an immediate effect on milk yield (MY), as well as a long-term MY effect after normal milking is resumed (Bar-Peled et al., 1995; Rémond et al., 1999). The positive long-term carry-over effect on MY of increased MF can be achieved with a 2- to 3-wk treatment of 4 times a day $(4 \times)$ milking compared with twice a day $(\mathbf{2} \times)$ milking alone (Hale et al., 2003; Wall and McFadden, 2007). The negative carryover effect on MY in response to decreased MF has also been demonstrated following once-a-day $(\mathbf{1} \times)$ milking, although in this case, a $1 \times$ treatment of at least $6 \mathrm{wk}$ is required (Rémond et al., 1999).

Unilateral MF (UMF) experiments, in which udder halves are milked at different frequencies independently of one another, have demonstrated that the effects of MF on MY are predominantly controlled by intramammary factors (Stelwagen and Knight, 1997; Wall and McFadden, 2007; Murney et al., 2015a). Milk yield is ultimately affected by a combination of the number of secretory mammary epithelial cells (MEC) and their level of activity; therefore, factors and signaling pathways that modulate these parameters are the most plausible candidate mechanisms driving the response to changes in MF. Comparison of $4 \times$ milking with $1 \times$ milking by UMF in early lactation demonstrated an increase in both proliferation and the mRNA abundance of the major milk protein genes in response to the higher MF (Murney et al., 2015a). Furthermore, analysis of mammary tissue from these treatments showed that signaling proteins involved in prolactin and extracellular matrix signaling pathways seem to be affected by MF (Murney et al., 2015b). However, these effects do not provide a full mechanistic description of how the MF effects are mediated in the mammary gland. Thus, further candidate pathways and factors should be investigated.

Insulin-like growth factor-I (IGF-I) is a candidate factor that may be involved in the effects of MF. This endocrine hormone is synthesized in the liver in response to growth hormone and it circulates in the 
bloodstream at a relatively high concentration. In addition, IGF-I can be locally produced within several different tissues, including mammary glands, thereby acting as an autocrine hormone (Glimm et al., 1992). This locally produced IGF-I is thought to be as important to mammary gland development as systemic IGF-I (Akers et al., 2000).

The majority of IGF-I found in circulation is bound with high affinity to one or more of the 6 known IGF binding proteins (IGFBP 1-6), which modulate the bioavailability of IGF-I to target tissues (Flint et al., 2008). In mammary glands, locally synthesized IGFBP3 and IGFBP5 are thought to be important for controlling IGF-I function (Flint et al., 2008). The upregulation of IGFBP5 has been demonstrated in rodent mammary glands at the onset of involution and is thought to inhibit the cell survival signal of IGF-I (Tonner et al., 1997; Flint et al., 2005). The effects of IGF-I on cellular function can also be moderated by changes in the levels of the IGF type I receptor (IGFIR), which is the primary signaling receptor for IGF-I (Baumrucker and Erondu, 2000).

Insulin-like growth factor-I is a potent mammary mitogen and has been shown both to have proliferative properties in bovine MEC in vitro (McGrath et al., 1991) and to protect against apoptosis in mouse mammary glands during involution (Neuenschwander et al., 1996). Furthermore, IGF-I has been shown to increase milk secretion in goats when administered via close arterial injection (Prosser et al., 1990). Interestingly, this effect is masked by a preceding treatment of increased MF, suggesting some link between the effect of IGF-I and the effect of MF (Prosser and Davis, 1992).

Previous studies have reported changes in components of the IGF-I signaling pathway within mammary glands in response to MF (Bernier-Dodier et al., 2010; Littlejohn et al., 2010; Wall and McFadden, 2010; Boutinaud et al., 2013). The abundance of $I G F-I$ and IGFIR mRNA increased in mammary tissue that was subjected to 3 -times-a-day $(\mathbf{3} \times)$ milking in midlactation compared with $1 \times$ milking, whereas IGFBP5 mRNA was not affected (Bernier-Dodier et al., 2010). In contrast, microarray analysis of genes modulated in response to $1 \times$ milking revealed an increase of IGFBP 5 mRNA abundance in $1 \times$-milked udder halves compared with $2 \times$ (Littlejohn et al., 2010; Boutinaud et al., 2013). In another study comparing $4 \times$ and $2 \times$ milking in early lactation, no MF effect was observed on $I G F-I$ and IGFIR mRNA abundance, but lower amounts of IGFBP3 mRNA were observed in $4 \times$-milked mammary tissues compared with $2 \times$ (Wall and McFadden, 2010). This response of IGFBP 3 mRNA to MF was only detected when the tissue was collected following a $4 \times$ milking, whereas samples taken when both udder halves were milked showed no difference in IGFBP3 mRNA abundance (Wall and McFadden, 2010). Overall, the differing findings of these studies only serve to illustrate the complex and dynamic nature of IGF-I signaling in bovine mammary glands, which is not fully understood.

Two intracellular pathways are thought to be stimulated by IGF-I: the phosphoinositide 3-kinase (PI3K)/Akt and extracellular-signal-regulated kinase (ERK)1/2 pathways (Peruzzi et al., 1999). The serine/ threonine kinase Akt is an important intracellular node in cell signaling, which is activated by IGF-I as well as other growth factors, cytokines, and the extracellular matrix. Activation of Akt is known to protect against apoptosis (Kennedy et al., 1997) and overexpression of activated Akt within the mammary glands of transgenic mice can delay the onset of involution (Hutchinson et al., 2001). The ERK1/2 pathway is also stimulated by IGF-I as well as by other mitogenic stimuli. Activation of the ERK1/2 pathway is involved in a diverse range of cellular processes that control functions such as cell cycle progression, cell proliferation, cell division, and cell differentiation. The activation of ERK1/2 is essential for appropriate development of mammary glands controlling MEC proliferation (Whyte et al., 2009). These signaling intermediates thus represent likely downstream candidate mediators of the MF response in mammary glands.

We hypothesized that MF modulates the IGF-I signaling pathway within mammary glands by altering the expression of locally produced IGF-I, IGFBP, and IGFIR. This would in turn lead to activation of the PI3K/Akt or ERK1/2 pathways, or both, which results in modulation of the rate of MEC turnover by altering levels of apoptosis and proliferation. To test this hypothesis, we measured several key components of the IGF-I signaling pathway in a $4 \times / 1 \times$ UMF model.

\section{MATERIALS AND METHODS}

\section{Animals and Treatments}

All animal manipulations were conducted in compliance with the rules and guidelines of the Ruakura Animal Ethics Committee. Animal management and treatments have been described in detail previously (Murney et al., 2015a). Briefly, half udders from 17 Holstein-Friesian and Holstein-Friesian $\times$ Jersey dairy cows in the first week of lactation $(5 \pm 2$ DIM) were randomly assigned to MF treatment, either $4 \times$ or $1 \times$ $(4 \times$ in one udder half at $0500,1100,1700$, and 2300 $\mathrm{h}$, and $1 \times$ in the other udder half at $1100 \mathrm{~h}$ ) for $14 \mathrm{~d}$. The pretreatment MY of the udder halves were $8.4 \pm$ 0.5 and $8.5 \pm 0.5 \mathrm{~kg} / \mathrm{d}$ for $4 \times$ and $1 \times$, respectively. By 
Table 1. Primers used for real-time PCR

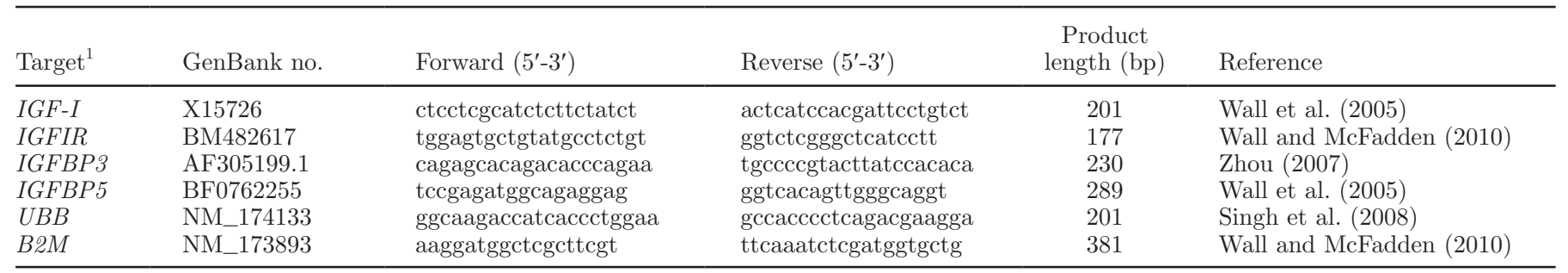

${ }^{1} I G F I R=$ IGF type I receptor; $I G F B P=$ IGF binding protein; $U B B=$ ubiquitin B; $B 2 M=\beta-2$ microglobulin.

d 14 of treatment, the $4 \times$ and $1 \times$ udder half MY were $15.0 \pm 0.7$ and $7.5 \pm 0.3 \mathrm{~kg} / \mathrm{d}$, respectively. Biopsies of mammary gland tissue were taken from both rear quarters of 10 cows at between 3 and $5 \mathrm{~h}$ following the $1100 \mathrm{~h}$ milking on $\mathrm{d} 14$, as previously described (Farr et al., 1996). Briefly, this involved excision of approximately $0.5 \mathrm{~g}$ of alveolar tissue from a site distal from the cistern and major ducts using a modified, purpose-built drill rotating stainless steel cannula. The tissue samples were snap frozen in liquid nitrogen for subsequent molecular analysis of mRNA and protein.

\section{RNA Isolation and Reverse Transcription}

The total RNA was isolated from $100 \mathrm{mg}$ of mammary tissue using Trizol reagent (Life Technologies, Grand Island, NY) according to the manufacturer's instructions and quantified using a Nanodrop 1000 spectrophotometer (Nanodrop, Wilmington, DE). The RNA integrity was measured on an Agilent 2100 Bioanalyzer (Agilent, Santa Clara, CA) with an RNA integrity number (RIN) $>5$ considered sufficient for real-time reverse transcription (RT)-PCR analysis. For cDNA synthesis, $1 \mu \mathrm{g}$ of total RNA was purified using RNAeasy columns (Qiagen, Valencia, CA), as per the supplied RNA clean-up protocol (Qiagen) and converted using the SuperScript III reverse transcription kit (Life Technologies) according to the manufacturer's instructions. The amount of cDNA equivalent to $5 \mathrm{ng}$ of starting total RNA was used as template for each real-time PCR reaction. Primer pairs for genes of interest and housekeeper genes are listed in Table 1. Primers have previously been reported for IGF-I and IGFBP 5 (Wall et al., 2005), IGFIR, and $\beta 2$ microglobulin (B2M; Wall and McFadden, 2010), IGFBP3 (Zhou, 2007), and ubiquitin B ( $\boldsymbol{U} \boldsymbol{B} \boldsymbol{B}$; Singh et al., 2008). Real-time PCR was carried out on a Corbett Rotorgene 6000 (Qiagen) with SYBR ExTaq Mix (Takara Bio Inc., Shiga, Japan) with a 3-min denaturation, followed by 40 cycles of $95^{\circ} \mathrm{C}$ for $10 \mathrm{~s}$ and $60^{\circ} \mathrm{C}$ for $30 \mathrm{~s}$. The mRNA abundance for genes of interest were calculated relative to the geometric mean of the mRNA abundance of 2 housekeeper genes ( $U B B$ and $B 2 M$ ) as previously described (Smith et al., 2010), with these modifications; threshold crossover values $\left(\mathrm{C}_{\mathrm{t}}\right)$ were replaced with take-off values and amplification efficiencies were calculated using the comparative quantification analysis tool of Rotogene 6000 series software 1.7 (Qiagen). The PCR products were verified by sequencing (Waikato DNA Sequencing Facility, Hamilton, New Zealand).

\section{Protein Extraction and Western Blotting}

Total protein was isolated from snap-frozen mammary biopsy samples by homogenization in a buffer containing $10 \mathrm{~m} M$ HEPES, pH 7.9, $1.5 \mathrm{mM} \mathrm{MgCl}, 10 \mathrm{mM}$ $\mathrm{KCl}$, and protease inhibitors as described previously (McMahon et al., 2004). Protein concentration was determined using the Bradford method (Bradford, 1976), and $20 \mu \mathrm{g}$ of total protein was separated on $10 \%$ BisTris NUPAGE gels (Life Technologies) and transferred onto nitrocellulose membranes (Pall Corporation, East Hills, NY). Membranes were blocked in Tris-buffered saline (TBS) solution (0.05 $M$ Tris- $\mathrm{HCl}, 0.15 \mathrm{M} \mathrm{NaCl}, \mathrm{pH}$ 7.6) containing $0.1 \%$ Tween 20 (TBST), 0.1\% BSA, and $4 \%$ nonfat milk for $2 \mathrm{~h}$. After 3 washes in TBSTBSA, membranes were incubated for $2 \mathrm{~h}$ in TBST-BSA with antibodies targeting ERK1/2 (1:10,000, sc-94, Santa Cruz Biotechnology, Santa Cruz, CA), Thr 202/ Thr 204 phosphorylated ERK1/2 (ERK-P, 1:500, sc-16982-R, Santa Cruz Biotechnology), Akt1/2/3 (1:1,000, sc-8312, Santa Cruz Biotechnology), and Ser 473 phosphorylated Akt1/2/3 (Akt-P, 1:5,000, sc7985-R, Santa Cruz Biotechnology). Following 3 further washes in TBST-BSA, membranes were incubated for 1 $\mathrm{h}$ in TBST-BSA with a 1:10,000 dilution of goat antirabbit secondary antibody conjugated to horseradish peroxidase (Sigma-Aldrich Co. Ltd., Gillingham, UK). Finally, membranes were washed in TBST-BSA 3 times and then washed a further 4 times in TBS. To visualize the immunoreactive bands, membranes were incubated for $1 \mathrm{~min}$ in ECL Western blotting detection reagents (Amersham, GE Healthcare, Amersham, UK) and then exposed to X-Omat AR film (Carestream Health Inc., Rochester, NY) for 2 to $30 \mathrm{~min}$, depending on the protein of interest. Films were scanned using a densitom- 


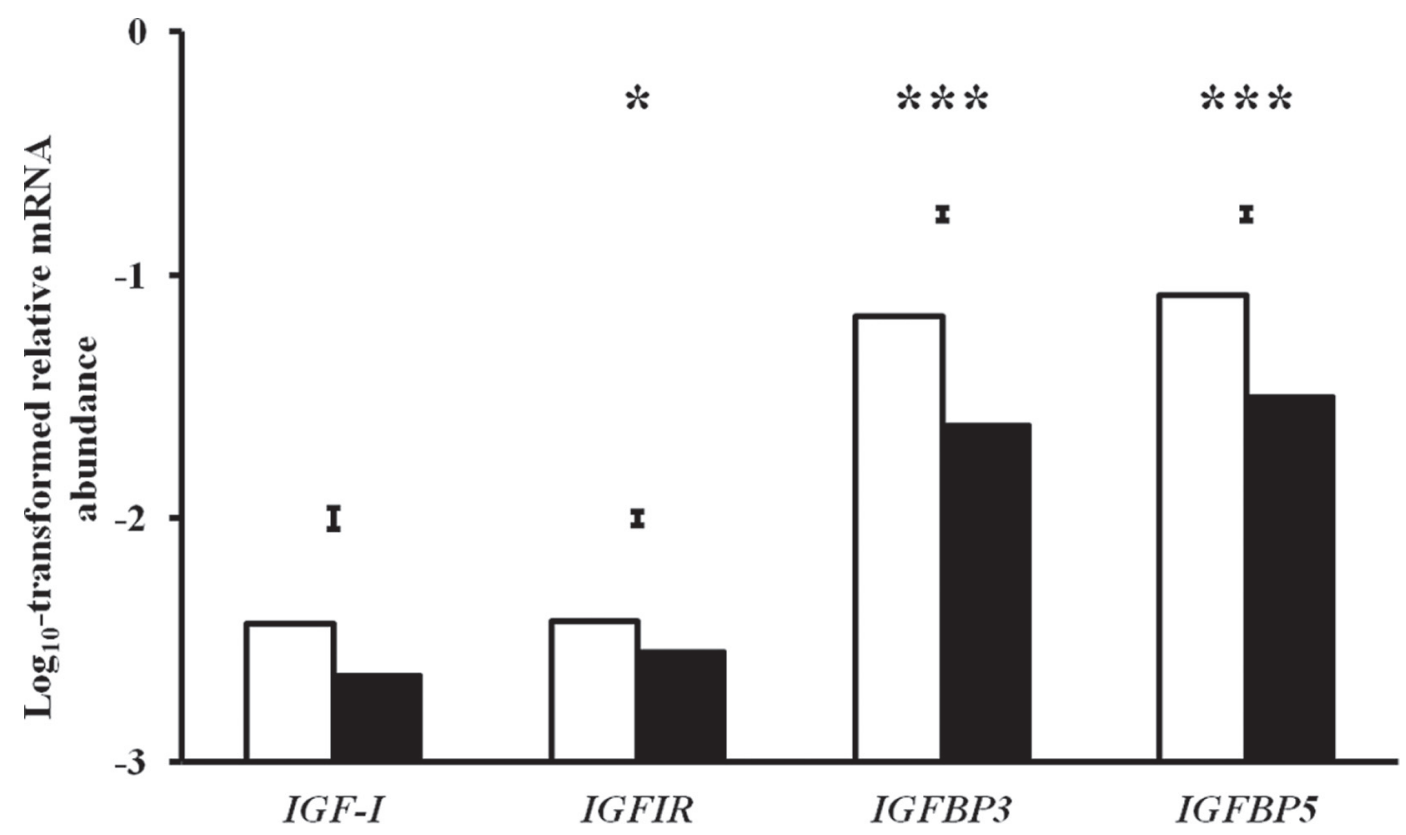

Figure 1. Relative mRNA abundance for IGF-1 associated genes of interest in mammary tissue collected from dairy cow udder halves unilaterally milked 4 times a day $(4 \times$; solid bars) or once a day $(1 \times$; open bars) for $14 \mathrm{~d}$ in early lactation. Abundance of $I G F-I$, IGF type I receptor (IGFIR), IGF binding protein 3 (IGFBP3), and IGF binding protein 5 (IGFBP5) mRNA was determined relative to 2 housekeeper genes (ubiquitin B and $\beta 2$ microglobulin) and expressed as $\log _{10}$-transformed treatment mean. Bars indicate the standard error of the difference between the treatment mean: ${ }^{*} P \leq 0.05$ and ${ }^{* * *} P \leq 0.001$.

eter (GS 800, BioRad, Auckland, New Zealand) and the densities of immunoreactive bands were determined using Quantity One software (BioRad).

\section{Statistical Analysis}

Differences between $\log _{10}$-transformed relative mRNA abundance and $\log _{10}$-transformed protein densities were analyzed by ANOVA (Minitab 16.2.2, 2010, State College, PA) by treatment (MF), with cow as a random effect. $\log _{10}$-transformed relative mRNA abundance was expressed as treatment mean. The fold change with treatment was calculated by back-transformation of the difference between the treatment means $(4 \times-1 \times)$. $\log _{10}$-transformed protein densities were expressed as a ratio of treatment mean $(4 \times: 1 \times) \pm$ standard error of the difference. Differences between means were considered significant at $P<0.05$.

\section{RESULTS}

\section{Effects of MF on Genes of the IGF-I Axis}

The relative abundance of IGF-I, IGFIR, IGFBP3, and $I G F B P 5 \mathrm{mRNA}$ were measured in mammary tissue extracted from udder halves either milked $4 \times$ or $1 \times$ for $14 \mathrm{~d}$ in early lactation. We detected no significant difference between $4 \times$ - and $1 \times$-milked mammary tissues for
$I G F-I$ mRNA (Figure 1). On the other hand, 2.6- and 2.8 -fold decreases in the relative abundance of IGFBP 3 and IGFBP5 mRNA, respectively, were detected in $4 \times$-milked mammary tissues compared with $1 \times$-milked mammary tissues (Figure 1). In addition, there was a 1.3-fold decrease in the relative abundance of IGFIR mRNA also detected in $4 \times$-milked mammary tissues compared with $1 \times$-milked mammary tissues (Figure 1 ). These results show that in mammary glands, MF does alter the expression of some components of the IGF-I signaling pathway.

\section{Effects of MF on the Activation of PI3K/Akt and $E R K 1 / 2$}

Insulin-like growth factor-I is known to stimulate both the PI3K/Akt and ERK1/2 pathways resulting in the phosphorylation of the Akt and ERK1/2 proteins. The abundance of Akt and ERK1/2 and the abundance of the phosphorylated forms of these proteins were therefore measured in mammary tissue extracted from udder halves either milked $4 \times$ or $1 \times$ for $14 \mathrm{~d}$ in early lactation. The abundance of Akt protein was similar between both treatments, whereas the abundance of Akt-P in $4 \times$-milked mammary tissues was approximately one-third of that in the $1 \times$-milked mammary tissues (Figure 2). This difference was significant, indicating that increased MF decreased Akt signaling. 

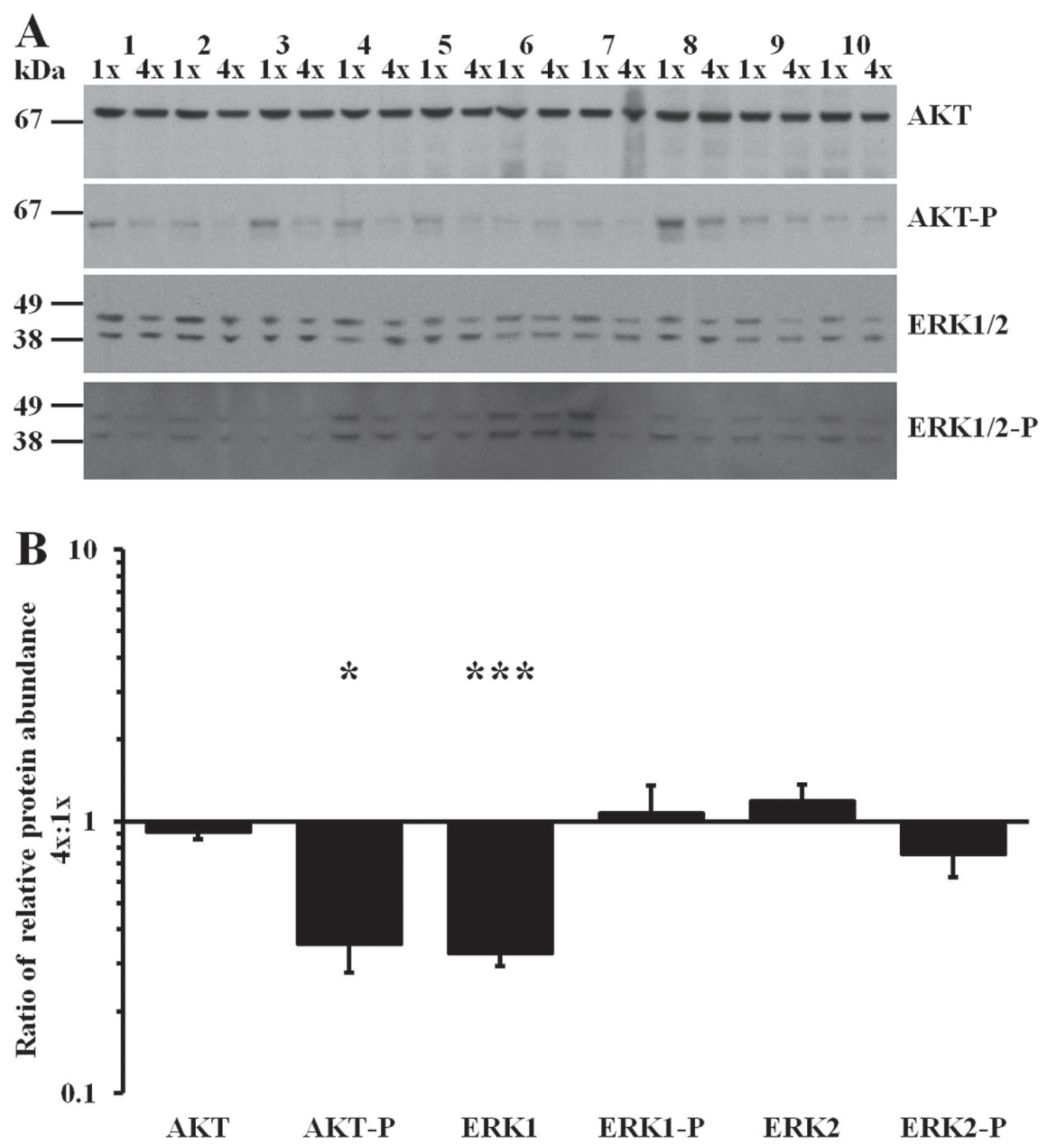

Figure 2. Western blot analysis of key proteins in the phosphoinositide 3-kinase/Akt and extracellular-signal-regulated kinase (ERK) signaling pathways in mammary tissue extracted from udder halves of dairy cows which had been unilaterally milked 4 times a day $(4 \times)$ or once a day $(1 \times)$ for $14 \mathrm{~d}$ in early lactation. (A) Independent Western blots for Akt, phosphorylated Akt (Akt-P), ERK1/2, and phosphorylated ERK1/2 (ERK1/2-P) in total protein samples extracted from both the $4 \times$-and $1 \times$-milked udder halves of 10 dairy cows. (B) Difference of the mean protein levels as determined by densitometry of Akt, Akt-P, ERK1 ( $\sim 44 \mathrm{kDa}$ band), ERK2 ( $\sim 42 \mathrm{kDa}$ band), ERK1-P, and ERK2-P expressed as a ratio in the $4 \times$ compared with the $1 \times$ ( \pm standard error of the difference); ${ }^{*} P \leq 0.05$ and $* * * P \leq 0.001$.

The ERK antibody detected 2 protein bands, ERK1 $(\sim 44 \mathrm{kDa}$ band $)$ and ERK2 ( $\sim 2 \mathrm{kDa}$ band $)$ in the mammary tissue samples. The total protein abundance of ERK1 in $4 \times$-milked mammary tissues was approximately one-third of that in the $1 \times$-milked mammary tissues (Figure 2), whereas the protein abundance of ERK2 did not differ between treatments (Figure 2). We found no significant difference between treatments in the abundance of either ERK1-P or ERK2-P (Figure 2 ), which indicates that MF does not affect the overall activation of the ERK1/2 signaling pathway but that it does affect ERK1 protein abundance.

\section{DISCUSSION}

We measured expression of components of the IGF-I axis to determine whether alteration of MF in early lactation can affect IGF-I signaling in bovine mammary glands. The results revealed that MF can affect the IGF-I signaling pathway in mammary glands by de- 
creasing IGFBP3 and IGFBP5 mRNA expression with increased MF, which should increase the bioavailability IGF-I in the $4 \times$-milked mammary tissues.

Previous studies have shown there appears to be a window of opportunity in early lactation (the first $3 \mathrm{wk}$ postpartum) when short-term treatments of increased MF can elicit a long-term effect on MY (Hale et al., 2003; Wall and McFadden, 2007; Murney et al., 2015a). Interestingly, Plath-Gabler et al. (2001) reported that this stage of lactation is when the expression of IGFBP 5 mRNA in the mammary gland is at its peak. Data from this study revealed that, in early lactation, $4 \times$-milked mammary tissues had a lower abundance of IGFBP3 and IGFBP5 mRNA compared with $1 \times$-milked mammary tissues. It is plausible that the decrease in expression of IGFBPs could increase the bioavailability of IGF-I in the $4 \times$-milked mammary tissues, which could be one factor contributing to the higher level of proliferation previously reported in $4 \times$-milked mammary tissues (Murney et al., 2015a). The idea of downregulation of IGFBPs in the mammary gland in response to increased MF, increasing the bioavailability of IGF-I, may also explain the results obtained by Prosser and Davis (1992). The study conducted by Prosser and Davis (1992) demonstrated that lactogenic effects of close arterial infusion of IGF-I into the mammary gland in goats is not apparent if an increased MF treatment is applied to the mammary gland on the day preceding infusion. It is possible in the Prosser and Davis (1992) study that the MF treatment suppressed expression of IGFBPs and therefore increased IGF-I bioavailability to a level close to saturation. Under these conditions, subsequent introduction of exogenous IGF-I would have little effect on milk production, as was observed (Prosser and Davis, 1992).

An increase in expression of IGFBP5 in rodent mammary glands during involution coincides with an increase in MEC apoptosis (Tonner et al., 1997). It is thought that the increase in IGFBP5 sequesters any free IGF-I and therefore inhibits the IGF-I activation of the antiapoptotic PI3K/Akt pathway (Tonner et al., 2002). The data from this study suggest that in bovine mammary glands during early lactation, there seems to be no link between the expression of IGFBP5 and the activation of PI3K/Akt pathway. Instead, the activation of Akt is independent of the abundance of IGFBP5 mRNA, with Akt activation being highest in the $1 \times$-milked mammary tissues. One possible explanation is that another, as yet unidentified, signal activates the PI3K/Akt pathway in response to $1 \times$ milking. Furthermore, activation of the PI3K/Akt pathway in $1 \times$-milked mammary tissues may explain why no increase in apoptosis was observed in these tissues in response to $1 \times$ milking (Murney et al., 2015a).

\section{CONCLUSIONS}

The data presented suggest that the IGF-axis can be modulated by changes in MF in bovine mammary glands in early lactation. This modulation is primarily mediated by the levels of expression of IGFBP 3 and $I G F B P 5$ mRNA, which decreased in response to increased MF. This may indicate increased bioavailability of IGF-I in the $4 \times$-milked mammary tissues, which could account for the increased proliferation and secretory activity measured in the $4 \times$-milked mammary tissues (Murney et al., 2015a). However, it is unclear which pathway is mediating the IGF-I signal within MEC, as increased activation for both the ERK1/2 and $\mathrm{PI} 3 \mathrm{~K} /$ Akt pathways was not detected in response to increased MF. The PI3K/Akt pathway activation was higher in the $1 \times$-milked mammary tissues, which suggests that IGF-I may not be the major factor stimulating this pathway in bovine mammary glands in early lactation. However, as activation of Akt is known to be antiapoptotic, stimulation of Akt activity during $1 \times$ milking may account for the lack of apoptosis that was detected in the mammary tissues following this treatment.

\section{ACKNOWLEDGMENTS}

The authors acknowledge Bruno Botaro, Eric Brijs, Chris Couldrey, Brad Hine, Kara Swanson, and the farm staff at the Tokanui Research Farm (AgResearch, Hamilton, New Zealand) for assistance with the animal trial and sample collections. We also acknowledge Harold Henderson (AgResearch) for his advice in statistical analysis. This research was funded by a Ministry of Business, Innovation \& Employment (New Zealand) research grant C10X0702.

\section{REFERENCES}

Akers, R. M., T. B. McFadden, S. Purup, M. Vestergaard, K. Sejrsen, and A. V. Capuco. 2000. Local IGF-I axis in peripubertal ruminant mammary development. J. Mammary Gland Biol. Neoplasia 5:43-51.

Bar-Peled, U., E. Maltz, I. Bruckental, Y. Folman, Y. Kali, H. Gacitua, A. R. Lehrer, C. H. Knight, B. Robinzon, and H. Voet. 1995. Relationship between frequent milking or suckling in early lactation and milk production of high producing dairy cows. J. Dairy Sci. 78:2726-2736.

Baumrucker, C. R., and N. E. Erondu. 2000. Insulin-like growth factor (IGF) system in the bovine mammary gland and milk. J. Mammary Gland Biol. Neoplasia 5:53-64.

Bernier-Dodier, P., L. Delbecchi, G. F. Wagner, B. G. Talbot, and P. Lacasse. 2010. Effect of milking frequency on lactation persistency and mammary gland remodeling in mid-lactation cows. J. Dairy Sci. 93:555-564.

Boutinaud, M., L. Galio, V. Lollivier, L. Finot, S. Wiart, D. Esquerré, and E. Devinoy. 2013. Unilateral once daily milking locally induces differential gene expression in both mammary tissue and milk epi- 
thelial cells revealing mammary remodeling. Physiol. Genomics 45:973-985.

Bradford, M. M. 1976. A rapid and sensitive method for the quantitation of microgram quantities of protein utilizing the principle of protein dye binding. Anal. Biochem. 72:248-254.

Farr, V. C., K. Stelwagen, L. R. Cate, A. J. Molenaar, T. B. McFadden, and S. R. Davis. 1996. An improved method for the routine biopsy of bovine mammary tissue. J. Dairy Sci. 79:543-549.

Flint, D. J., M. Boutinaud, E. Tonner, C. J. Wilde, W. Hurley, P. A. Accorsi, A. F. Kolb, C. B. A. Whitelaw, J. Beattie, and G. J. Allan. 2005. Insulin-like growth factor binding proteins initiate cell death and extracellular matrix remodeling in the mammary gland. Domest. Anim. Endocrinol. 29:274-282.

Flint, D. J., E. Tonner, J. Beattie, and G. J. Allan. 2008. Role of insulin-like growth factor binding proteins in mammary gland development. J. Mammary Gland Biol. Neoplasia 13:443-453.

Glimm, D. R., V. E. Baracos, and J. J. Kennelly. 1992. Northern and in situ hybridization analyses of the effects of somatotropin on bovine mammary gene expression. J. Dairy Sci. 75:2687-2705.

Hale, S. A., A. V. Capuco, and R. A. Erdman. 2003. Milk yield and mammary growth effects due to increased milking frequency during early lactation. J. Dairy Sci. 86:2061-2071.

Hutchinson, J., J. Jin, R. D. Cardiff, J. R. Woodgett, and W. J. Muller. 2001. Activation of Akt (protein kinase B) in mammary epithelium provides a critical cell survival signal required for tumor progression. Mol. Cell. Biol. 21:2203-2212.

Kennedy, S. G., A. J. Wagner, S. D. Conzen, J. Jordán, A. Bellacosa P. N. Tsichlis, and N. Hay. 1997. The PI 3-kinase/Akt signaling pathway delivers an anti-apoptotic signal. Genes Dev. 11:701-713.

Littlejohn, M. D., C. G. Walker, H. E. Ward, K. B. Lehnert, R. G. Snell, G. A. Verkerk, R. J. Spelman, D. A. Clark, and S. R. Davis. 2010. Effects of reduced frequency of milk removal on gene expression in the bovine mammary gland. Physiol. Genomics 41:21-32.

McGrath, M. F., R. J. Collier, D. R. Clemmons, W. H. Busby, C. A. Sweeny, and G. G. Krivi. 1991. The direct in vitro effect of insulin-like growth factors (IGFs) on normal bovine mammary cell proliferation and production of IGF binding proteins. Endocrinology 129:671-678.

McMahon, C. D., V. C. Farr, K. Singh, T. T. Wheeler, and S. R. Davis. 2004. Decreased expression of $\beta 1$-integrin and focal adhesion kinase in epithelial cells may initiate involution of mammary glands. J. Cell. Physiol. 200:318-325.

Murney, R., K. Stelwagen, T. T. Wheeler, J. K. Margerison, and K. Singh. 2015a. The effects of milking frequency in early lactation on milk yield, mammary cell turnover and secretory activity in grazing dairy cows. J. Dairy Sci. 98:305-311.

Murney, R., K. Stelwagen, T. T. Wheeler, J. K. Margerison, and K. Singh. 2015b. STAT5 activation is linked to $\beta 1$-integrin protein abundance in unilaterally milked bovine mammary glands. J. Dairy Sci. 98:3133-3142.

Neuenschwander, S., A. Schwartz, T. L. Wood, C. T. Roberts Jr., L. Henninghausen, and D. LeRoith. 1996. Involution of the lactating mammary gland is inhibited by the IGF system in a transgenic mouse model. J. Clin. Invest. 97:2225-2232.

Peruzzi, F., M. Prisco, M. Dews, P. Salomoni, E. Grassilli, G. Romano, B. Calabretta, and R. Baserga. 1999. Multiple signaling pathways of the insulin-like growth factor 1 receptor in protection from apoptosis. Mol. Cell. Biol. 19:7203-7215.
Plath-Gabler, A., C. Gabler, F. Sinowatz, B. Berisha, and D. Schams 2001. The expression of the IGF family and GH receptor in the bovine mammary gland. J. Endocrinol. 168:39-48.

Prosser, C. G., and S. R. Davis. 1992. Milking frequency alters the milk yield and mammary blood flow response to intra-mammary infusion of insulin-like growth factor-I in the goat. J. Endocrinol. 135:311-316.

Prosser, C. G., I. R. Fleet, A. N. Corps, E. R. Froesch, and R. B. Heap. 1990. Increase in milk secretion and mammary blood flow by intraarterial infusion of insulin-like growth factor-I into the mammary gland of the goat. J. Endocrinol. 126:437-443.

Rémond, B., J. B. Coulon, M. Nicloux, and D. Levieux. 1999. Effect of temporary once-daily milking in early lactation on milk production and nutritional status of dairy cows. Ann. Zootech. (Paris) 48:341-352.

Singh, K., S. R. Davis, J. M. Dobson, A. J. Molenaar, T. T. Wheeler, C. G. Prosser, V. C. Farr, K. Oden, K. M. Swanson, C. V. C Phyn, D. L. Hyndman, T. Wilson, H. V. Henderson, and K. Stelwagen. 2008. cDNA microarray analysis reveals that antioxidant and immune genes are upregulated during involution of the bovine mammary gland. J. Dairy Sci. 91:2236-2246.

Smith, C. S., D. K. Berg, M. Berg, and P. L. Pfeffer. 2010. Nuclear transfer-specific defects are not apparent during the second week of embryogenesis in cattle. Cell. Reprogram. 12:699-707.

Stelwagen, K., and C. H. Knight. 1997. Effect of unilateral once or twice daily milking of cows on milk yield and udder characteristics in early and late lactation. J. Dairy Res. 64:487-494.

Tonner, E., M. C. Barber, G. J. Allan, J. Beattie, J. Webster, C. B. A. Whitelaw, and D. J. Flint. 2002. Insulin-like growth factor binding protein-5 (IGFBP-5) induces premature cell death in the mammary glands of transgenic mice. Development 129:4547-4557.

Tonner, E., M. C. Barber, M. T. Travers, A. Logan, and D. J. Flint. 1997. Hormonal control of insulin-like growth factor-binding protein-5 production in the involuting mammary gland of the rat. Endocrinology 138:5101-5107.

Wall, E. H., T. L. Auchtung, G. E. Dahl, S. E. Ellis, and T. B. McFadden. 2005. Exposure to short day photoperiod during the dry period enhances mammary growth in dairy cows. J. Dairy Sci. 88:1994-2003.

Wall, E. H., and T. B. McFadden. 2007. Optimal timing and duration of unilateral frequent milking during early lactation of dairy cows. J. Dairy Sci. 90:5042-5048.

Wall, E. H., and T. B. McFadden. 2010. The effects of milk removal or four-times-daily milking on mammary expression of genes involved in the insulin-like growth factor-I axis. J. Dairy Sci. 93:4062-4070.

Whyte, J., O. Bergin, A. Bianchi, S. McNally, and F. Martin. 2009. Key signalling nodes in mammary gland development and cancer. Mitogen-activated protein kinase signalling in experimental models of breast cancer progression and in mammary gland development. Breast Cancer Res. 11:209.

Zhou, Y. 2007. Effects of growth hormone and insulin-like growth factor-I on milk protein gene expression and nutrient uptake and cell proliferation in clonal bovine mammary epithelial cells. PhD Thesis. Virginia Polytechnic Institute and State University, Blacksburg. 